\title{
Editorial
}

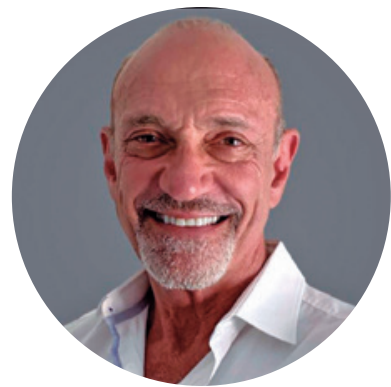

MARK MYERSON

EUA

Professor of Orthopedic Surgery, University of Colorado; Past President American Orthopedic Foot and Ankle Society; Editor in Chief Foot and Ankle Clinics North America; Executive Director and Founder, Steps2Walk

\section{A brief perspective of foot and ankle leadership over the decades}

I remember so clearly when I first became a member of the American Orthopedic Foot and Ankle Society in the early 1980s. I knew everyone. It was a small organization that facilitated friendships, collegiality as well as academic and professional interaction. Now as then, these incredible friendships that we have all established over the decades define our professional life.

For those of you who have been involved in the education of residents and fellows you will understand how relevant this is to your own personal growth. I have always felt strongly that you cannot be an educator unless you're prepared to listen to your students. In the earlier years of training fellows, it was not much of an age differential, and while there was always a matter of the difference in knowledge and experience, I did not yet have the "seniority". However, over the decades l've learned that some of our closest relationships emanate from these mentoring experiences. Here is a quote from Dr George Quill, a fellow in 1989: "In hindsight, I was doubly fortunate to be only the second surgeon in the world to matriculate with Mark Myerson because, in doing so, I gained a generous mentor and a dear friend for life!" Remember this: as an educator you inevitably give of yourself, but you will also receive something in return. When we share compassion with others, we are all tremendously enriched. Teaching of residents and fellows is a responsibility that we all share. During the formative training particularly of fellows, I want them "to lose their GPS". Residents learn by repetition, but this encourages sterility without analysis. And by following the acquisition of knowledge blindly without questioning and analyzing the process does not help one grow. This is what I mean about losing your GPS, since sooner or later our fellows need to break away from the mentality of being guided by their mentor's thinking and develop strategies of their own.

I have never been afraid to push the envelope of experiences, and I have always embraced intellectual, personal, academic, and professional challenges. Many of you may have heard me saying that life begins at the edge of your comfort zone. In my practice of medicine, I've never felt any room for complacency. To accept everything as given, whether we read it in a prominent journal, or hear it from a colleague is meaningless until we can prove it for ourselves. This I learned from my mentor, Dr. Melvin Jahss who insisted in the early 1980's that very few things were actually new ideas. He maintained that if one read the literature in depth, particularly in other languages, it was all there. I was reminded this many years later when I "rediscovered" what we know as today as the Ludloff osteotomy. I was sure that I had performed a new procedure. However, sure enough, my fellow at the time Dr. Hans Trnka found this technique referred to in the German literature, and although my technique was completely different since Ludloff did not use any fixation, the rest is history. 
Where do new ideas come from? I'm sure that all of you have said to yourselves at one point in time or another "oh, why did I not think of that?" As long as I can remember I have derived immense satisfaction and enrichment from research and investigation, and this passion has never diminished. It has been part of my life and continues to be an integral source of stimulation for me. Many of you do not have the resources nor access to research, but I am sure that all of you wonder about outcomes and results pertaining to your own innovative thinking. Try to share these ideas with others and find like-minded individuals who want to explore new ideas. Some of the most productive times for me have been when I am sitting quietly listening to music. When I go to the symphony orchestra, I scribble research notes and ideas onto the program. Multitasking it's something that for surgeons comes naturally. Find a quiet time for yourselves and just think, don't do!

As many of you know, l've devoted these past years to humanitarian service through an organization which I founded, Steps2Walk (www. steps 2 walk.org). This has been an extraordinary journey, and I and the others who have supported us either on our medical advisory board, or as surgeon volunteers have all been touched and blessed by this opportunity. The spectrum of deformities which we treat is indeed challenging, but by performing humanitarian service, one experiences the deep fulfillment that can only come from improving the lives of others. I truly believe that you cannot experience your practice of orthopedic surgery nor reach your potential until you do something for someone who can never repay you.

Steve Jobs said that "the people who are crazy enough to think that they can change the world are the ones who do". 